\title{
NONCLASSICAL EQUATIONS OF MATHEMATICAL PHYSICS. LINEAR SOBOLEV TYPE EQUATIONS OF HIGHER ORDER
}

\author{
A.A. Zamyshlyaeva, G.A. Sviridyuk \\ South Ural State University, Chelyabinsk, Russian Federation \\ E-mail: zamyshliaevaaa@susu.ru
}

The article presents the review of authors' results in the field of non-classical equations of mathematical physics. The theory of Sobolev-type equations of higher order is introduced. The idea is based on generalization of degenerate operator semigroups theory in case of the following equations: decomposition of spaces, splitting of operators' actions, the construction of propagators and phase spaces for a homogeneous equation, as well as the set of valid initial values for the inhomogeneous equation. The author uses a proven phase space technology for solving Sobolev type equations consisting of reduction of a singular equation to a regular one defined on some subspace of initial space. However, unlike the first order equations, there is an extra condition that guarantees the existence of the phase space. There are some examples where the initial conditions should match together if the extra condition can't be fulfilled to solve the Cauchy problem. The reduction of nonclassical equations of mathematical physics to the initial problems for abstract Sobolev type equations of high order is conducted and justified.

Keywords: nonclassical equations of mathematical physics; the Sobolev type equations of higher order; phase space, propagators.

\section{Introduction}

To the linear Sobolev type equations of high order we consider those non-classical equations of mathematical physics, which in suitable functional spaces can be reduced to the abstract operator differential equation of the form

$$
A u^{(n)}=B_{n-1} u^{(n-1)}+\ldots+B_{0} u,
$$

where $n \in N \backslash\{1\}$, operators $A, B_{n-1}, \ldots, B_{0}$ are linear and the operator $A$ might not have an inverse, in particularm when $\operatorname{ker} A \neq\{0\}$. Usually equation (1) is considered along with the Cauchy initial conditions

$$
u^{(m)}(0)=u_{m}, m=0, \ldots, n-1 .
$$

However it was shown [1] that the Showalter-Sidorov conditions

$$
A\left(u^{(m)}(0)-u_{m}\right)=0, m=0, \ldots, n-1
$$

are more natural for the Sobolev type equations. Problems (1), (2) and (1), (3) depending on the goals of investigation can be understood in different senses (classical,. в зависимости от целей исследования могут пониматься в различных смыслах (classical, generalized, weak, strong, etc.), however it is obvious that (3) is more general in comparison to (2). In a trivial case (when the inverse to $A$ exists) both problems coincide, therefore their solutions coincide. In this paper the Showalter-Sidorov conditions are considered in more general statement

$$
P\left(u^{(m)}(0)-u_{m}\right)=0, m=0, \ldots, n-1,
$$

where $P$ is a relative spectral projector. For conduction of computational experiments the Showalter Sidorov conditions are more suitable than the Cauchy conditions because there is no need to check if the initial data belongs to a phase space of the equation. Apparently A. Poincare [2] was the first to study equations of mathematical physics nonsolvable with respect to the highest derivative in time. However their systematic study was initiated by S.L. Sobolev [3] (see the historical review in [4]). By now there are a lot of methods and results of study of such equations. Their diversity is reflected the terminology: degenerate equations [5], pseudo parabolic equations [6] and even equations "of not CauchyKovalevskaya type" (cited by [4]). We use the term "Sobolev type equations" introduced by R. 


\section{Математика}

Showalter [7]. Firstly, we want to support the outstanding role of our great compatriot in a discovery of a new scientific direction. And the second reason is that this term is becoming more common [7-13].

Even a cursory glance at the vast area of nonclassical equations of mathematical physics [7, 14-16] can detect the variety of aspects in which they are investigated. Our approach is based on a phase space concept, the essence of which lies in a reduction of singular equation (1) to a regular one

$$
u^{(n)}=S_{n-1} u^{(n-1)}+\ldots+S_{0} u+g
$$

defined, however, not on a whole space but on some subset of initial space, containing all initial values (2). In our case the phase space is a subspace of initial space (we show this below) or (in the worst case) an affine manifold (see examples in [8]). In the semilinear case, the phase space is much more interesting, even if $n=1$ (see the review [17]).

To describe the morphology of the phase space of (1), it may seem that it is sufficient to reduce this equation using the standard procedure to a linear equation of the first order, the phase spaces of which are well studied [8]. However, on that way there arise unexpected difficulties: it turns out that in some cases $[18,19]$ for the solvability of problem (1), (2) the conditions of the Cauchy problem (2) need to be confirmed. For the relief of these difficulties there was proposed [20] a condition (see paragraph 1 of this article). The discussion of the role of this condition in the description of the phase space of equation (1) is the main content of the article. We should emphasize that there is no such a phenomena in the description of phase spaces of Sobolev type equations of the first order [8] and classical equations (5).

The article besides an introduction and references includes four paragraphs. The first one is devoted to the abstract Cauchy problem and propagators for the higher order Sobolev type equation with relatively $p$-bounded operator pencil [10]. These results are used to study the solvability of the initialboundary problem for the equation describing acoustic waves in a smectic [21] in the second paragraph, the Boussinesq-Love equation on a finite connected oriented graph [22] in the third paragraph, equations describing ion-acoustic waves in plasma [23] in the fourth.

Finally note that all considerations are held in real Banach spaces, but when studying spectral problems we introduce their natural complexification. All contours are oriented counterclockwise and bound the domain that lies to the left in this movement.

\section{Propagators}

Let $U, F$ be Banach spaces, operators $A, B_{0}, \ldots, B_{n-1} \in L(U ; F)$. Denote by $\vec{B}$ a pencil of operators $B_{n-1}, \ldots, B_{0}$.

Definition 1. The sets $\rho^{A}(\vec{B})=\left\{\mu \in C:\left(\mu^{n} A-\mu^{n-1} B_{n-1}-\ldots-\mu B_{1}-B_{0}\right)^{-1} \in L(F ; U)\right\} \quad$ and $\sigma^{A}(\vec{B})=\bar{C} \backslash \rho^{A}(\vec{B})$ are called an $A$-resolvent set and an $A$-spectrum of the operator pencil $\vec{B}$.

Definition 2. The operator-function of a complex variable $R_{\mu}^{A}(\vec{B})=\left(\mu^{n} A-\mu^{n-1} B_{n-1}-\ldots-\mu B_{1}-B_{0}\right)^{-1}$ with the domain $\rho^{A}(\vec{B})$ is called an $A$-resolvent of the pencil $\vec{B}$.

Lemma 1 [24]. Let the operators $A, B_{n-1}, \ldots, B_{0} \in L(U ; F)$.Then the $A$-resolvent set $\rho^{A}(\vec{B})$ of the operator pencil $\vec{B}$ is opened, the $A$-spectrum of the pencil $\vec{B}$ is always closed.

Theorem 1 [24]. $R_{\mu}^{A}(\vec{B})$ is analytical in its domain.

Definition 3. The operator pencil $\vec{B}$ is called polynomially bounded with respect to an operator $A$ (or simply polynomially $A$-bounded), if

$$
\exists a \in R_{+} \quad \forall \mu \in C \quad(|\mu|>a) \Rightarrow\left(R_{\mu}^{A}(\vec{B}) \in L(F ; U)\right) .
$$

Let the operator $\vec{B}$ be polynomially $A$-bounded. Introduce the following condition:

$$
\int_{\gamma} \mu^{k} R_{\mu}^{A}(\vec{B}) d \mu \equiv O, k=0,1, \ldots, n-2,
$$

where the contour $\gamma=\{\mu \in C:|\mu|=r>a\}$.

Lemma 2 [24]. Let the operator pencil $\vec{B}$ be polynomially A-bounded and condition (A) be fulfilled. Then the operators 


$$
P=\frac{1}{2 \pi i} \int_{\gamma} R_{\mu}^{A}(\vec{B}) \mu^{n-1} A d \mu, \quad Q=\frac{1}{2 \pi i} \int_{\gamma} \mu^{n-1} A R_{\mu}^{A}(\vec{B}) d \mu .
$$

are projectors in the spaces $U$ and $F$ respectively.

Put $U^{0}=\operatorname{ker} P, F^{0}=\operatorname{ker} Q, U^{1}=i m P, F^{1}=i m Q$. By $A^{k}\left(B_{l}^{k}\right)$ denote a restriction of the operator $A\left(B_{l}\right)$ onto $U^{k}, k=0,1 ; l=0,1, \ldots, n-1$.

Theorem 2 [24]. Let the operator pencil $\vec{B}$ be polynomially A-bounded and condition (A) be fulfilled. Then the operators actions split:

(i) $A^{k} \in L\left(U^{k} ; F^{k}\right), k=0,1$;

(ii) $B_{l}^{k} \in L\left(U^{k} ; F^{k}\right), k=0,1, l=0,1, \ldots, n-1$;

(iii) there exists an operator $\left(A^{1}\right)^{-1} \in L\left(F^{1} ; U^{1}\right)$.

(iv) there exists an operator $\left(B_{0}^{0}\right)^{-1} \in L\left(F^{0} ; U^{0}\right)$.

Denote $H_{0}=\left(B_{0}^{0}\right)^{-1} A^{0}, H_{k}=\left(B_{0}^{0}\right)^{-1} B_{n-k}^{0}, k=\overline{1, n-1}, S_{k}=\left(A^{1}\right)^{-1} B_{k}^{1}, k=\overline{0, n-1}$.

Corollary 1 [24]. Let the operator pencil $\vec{B}$ be polynomially A-bounded and condition $(A)$ be fulfilled. Then there exists a constant $b \in R_{+}(b \geq a) \quad \forall \mu \in C(|\mu|>b) \Rightarrow$

$$
R_{\mu}^{A}(\vec{B})=-\sum_{k=0}^{\infty}\left(\mu^{n} H_{0}-\ldots-\mu H_{n-1}\right)^{k}\left(B_{0}^{0}\right)^{-1}(I-Q)+\mu^{-n} \sum_{k=0}^{\infty}\left(\mu^{-1} S_{n-1}+\ldots+\mu^{-n} S_{0}\right)^{k}\left(A_{1}^{1}\right)^{-1} Q .
$$

Definition 1. Let $\operatorname{ker} A \neq\{0\}$, the vector $\phi_{0} \in \operatorname{ker} A \backslash\{0\}$ is called an eigenvector of an operator $A$. An ordered set of vectors $\left\{\phi_{1}, \phi_{2}, \ldots\right\}$ is called a chain of $\vec{B}$-joined vectors of an eigenvector $\phi_{0}$, if

$$
\begin{gathered}
A \phi_{0}=0 ; \\
A \phi_{1}=B_{n-1} \phi_{0} ; \\
A \phi_{2}=B_{n-1} \phi_{1}+B_{n-2} \phi_{0} ; \\
\ldots \\
A \phi_{n}=B_{n-1} \phi_{n-1}+B_{n-2} \phi_{n-2}+\ldots+B_{1} \phi_{1}+B_{0} \phi_{0} ; \\
A \phi_{n+q}=B_{n-1} \phi_{n+q-1}+B_{n-2} \phi_{n+q-2}+\ldots+B_{1} \phi_{q+1}+B_{0} \phi_{q} ; \\
q=1,2 . ., \quad \phi_{l} \notin \operatorname{ker} A \backslash\{0\}, l=1,2, \ldots
\end{gathered}
$$

For the $\vec{B}$-joined vector $\phi_{q}$ define its height equal to its index in the chain. The linear hull of all eigenvectors and $\vec{B}$-joined vectors of the operator $A$ is called a $\vec{B}$-root lineal. A closed $\vec{B}$-root lineal is called a $\vec{B}$-root space of an operator $A$. The chain of $\vec{B}$-joined vectors can be infinite. In particular it can be filled in with zeros if

$$
\phi_{0} \in \operatorname{ker} A \cap \operatorname{ker} B_{n-1} \cap \operatorname{ker} B_{n-2} \cap \ldots \cap \operatorname{ker} B_{1} \cap \operatorname{ker} B_{0} .
$$

But it is finite in the case of existence of such a $\vec{B}$-joined vector $\phi_{q}$, that $B_{n-1} \phi_{q}+B_{n-2} \phi_{q-1}+\ldots+B_{0} \phi_{q-n+1} \notin i m A$. The height $q$ of the last $\vec{B}$-joined vector in a finite chain $\left\{\phi_{1}, \phi_{2}, \ldots, \phi_{q}\right\}$ is called a length of this chain.

Definition 5. Define the family of operators $\left\{K_{q}^{1}, K_{q}^{2}, \ldots K_{q}^{n}\right\}$ as follows:

$$
\begin{gathered}
K_{0}^{s}=O, s \neq n, K_{0}^{n}=O \\
K_{1}^{1}=H_{0}, K_{1}^{2}=-H_{n-1}, \ldots, K_{1}^{s}=-H_{n+1-s}, \ldots, K_{1}^{n}=-H_{1} \\
K_{q}^{1}=K_{q-1}^{n} H_{0}, K_{q}^{2}=K_{q-1}^{1}-K_{q-1}^{n} H_{n-1}, \ldots, K_{q}^{s}=K_{q-1}^{s-1}-K_{q-1}^{n} H_{n+1-s}, \ldots, \\
K_{q}^{n}=K_{q-1}^{n-1}-K_{q-1}^{n} H_{1}, q=1,2, \ldots
\end{gathered}
$$

Definition 6. The point $\infty$ is called

(i) a removable singular point of the A-resolvent of the pencil $\vec{B}$, if $K_{1}^{1}=K_{1}^{2}=\ldots=K_{1}^{n} \equiv O$; 


\section{Математика}

(ii) a pole of order $p \in N$ of the $A$-resolvent of the pencil $\vec{B}$, if $K_{p}^{s} \neq O$ for some $s$ but $K_{p+1}^{s} \equiv O$ for arbitrary $s$;

(iii) essentially singular point of the A-резольвенты of the pencil $\vec{B}$, if $K_{p}^{n} \equiv \equiv$ for arbitrary $p \in N$.

Theorem 4 [24]. Let the pencil $\vec{B}$ be polynomially A-bounded and $\infty$ be

(i) a removable singular point of the function $R_{\mu}(\vec{B})$. Then the operator $A$ does not have $\vec{B}$-joined vectors, $\operatorname{ker} A=U^{0}, \operatorname{im} A=F^{1}$.

(ii) a pole of order $p \in N$ of the function $R_{\mu}^{A}(\vec{B})$. Then the length of every chain of $\vec{B}$-joined vectors of the operator $A$ is bounded by number $p$ (the chains of length $p$ do exist), and the $\vec{B}$-root lineal of the operator A coincides with the subspace $U^{0}$.

Theorem 3 [24]. Let the operators $A, B_{n-1}, \ldots, B_{0} \in L(U, F)$, operator $A$ be a Fregholm operator. Then the following statements are equivalent.

(i) The lengths of all chains of $\vec{B}$-joined vectors of an operator $A$ are bounded by $p \in\{0\} \cup N$.

(ii) The operator pencil $\vec{B}$ is polynomially $A$-bounded and $\infty$ is a pole of order not greater then $p$ of the $A$-resolvent of an operator pencil $\vec{B}$.

Definition 7. The vector-function $v \in C^{n}(R ; U)$, satisfying (1), is called a solution of this equation. If the solution $v=v(t)$ satisfies (2), then it is called a solution of (1), (2).

Definition 8. The operator-function $V(\cdot) \in C^{\infty}(R ; L(U))$ is called a propagator of (1), if for any $v \in U$ the vector-function $v(t)=V^{t} v$ is a solution of this equation.

Let the pencil $\vec{B}$ be polinomially $A$-bounded and $(A)$ be fulfilled. Fix the contour $\gamma=\{\mu \in C:|\mu|=r>a\}$ and consider the family of operators

$$
V_{k}^{t}=\frac{1}{2 \pi i} \int_{\gamma} R_{\mu}^{A}(\vec{B})\left(\mu^{n-k-1} A-\mu^{n-k-2} B_{n-1}-\ldots-B_{k+1}\right) e^{\mu t} d \mu, k=0,1, \ldots n-1, t \in R .
$$

Lemma 3 [24]. (i) For any $k=0,1, \ldots, n-1$ the operator-function $V_{k}^{t}$ is a propagator of (1).

(ii) For any $k=0,1, \ldots, n-1$ the operator-function $V_{k}^{t}$ is $n$ entire function.

(iii) $\left.\frac{d^{l}}{d t^{l}} V_{k}^{t}\right|_{t=0}=\left\{\begin{array}{l}P, l=k ; \\ O, l \neq k ;\end{array}\right.$ for all $k=0,1, \ldots, n-1, l=0,1, \ldots$.

Definition 9. The set $P \subset U$ is called a phase space of (1), if

(i) any solution $v=v(t)$ of (1) lies in $P$, i.e. $v(t) \in P \quad \forall t \in R$

(ii) for all $v_{k} \in P, k=\overline{0, n}$ there exists a unique solution of (1), (2).

Theorem 5 [24]. Let the pencil $\vec{B}$ be polinomially A-bounded, (A) be fulfilled, and $\infty-$ be pole of order $p \in\{0\} \cup N$ or its $A$-resolvent. Then the phase space of (1) coincides with the image of the projector $P$.

\section{The De Gennes equation of the acoustic waves in a smectic} firm

The equation of linear acoustic waves in a smectic [25], firstly obtained by P.G. de Gennes, has the

$$
\frac{\partial^{2}}{\partial t^{2}} \Delta_{3} u=\alpha_{1} \frac{\partial^{2}}{\partial z^{2}} \Delta_{2} u, \alpha_{1}>0
$$

where $\Delta_{3}=\Delta_{2}+\partial^{2} / \partial z^{2}, \Delta_{2}=\partial^{2} / \partial x_{1}^{2}+\partial^{2} / \partial x_{2}^{2}$. The initial model has sense in a cylindrical domain in variables $\left\{z, x_{1}, x_{2}\right\} \in[a, b] \times \Omega$. In the case of stabilized acoustic waves in a smectic

$$
u\left(x_{1}, x_{2}, z, t\right)=v\left(x_{1}, x_{2}, z\right) \exp (-i \omega t),
$$


the initial equation takes the form

$$
\frac{\partial^{2}}{\partial z^{2}}\left(\Delta_{2} v+\alpha_{2} v\right)+\alpha_{2} \Delta_{2} v=0, \alpha_{2}=\omega^{2} \alpha_{1}^{-1}
$$

Supply this equation with the initial and boundary conditions

$$
\begin{gathered}
v(x, 0)=v_{0}(x), \quad v_{z}(x, 0)=v_{1}(x), \quad x=\left(x_{1}, x_{2}\right) \in \Omega \\
v(x, z)=0, \quad(x, z) \in \partial \Omega \times R .
\end{gathered}
$$

The initial-boundary value problem for (12) can be described in terms of problem (2) for equation (1). For the reduction of (12), (13) to (1), (2), put

$$
U=\left\{v \in W_{q}^{l+2}(\Omega): v(x)=0, x \in \partial \Omega\right\}, \quad F=W_{q}^{l}(\Omega),
$$

where $W_{q}^{l}(\Omega)$ are the Sobolev spaces $2 \leq q<\infty$. Put for the convenience $\alpha=-\alpha_{2}, \Delta=\Delta_{2}$. Define operators $A, B_{1}$ and $B_{0}$ by formulas $A=\Delta-\alpha, B_{1}=O, B_{0}=\alpha \Delta$. For any $l \in\{0\} \cup N$ operators $A, B_{1}, B_{0} \in L(U ; F)$.

Define by $\left\{\lambda_{k}\right\}$ the set of eigenvalues of the homogeneous Dirichlet problem in a domain $\Omega$ for the Laplace operator $\Delta$, numbered in nonincreasing order taking into account their multiplicities, and by $\left\{\phi_{k}\right\}$ denote the family of the corresponding eigenfunctions orthonormal with respect, to the inner product $\langle\cdot, \cdot\rangle$ in $L^{2}(\Omega)$. Since $\left\{\phi_{k}\right\} \subset C^{\infty}(\Omega)$, then

$$
\mu^{2} A-B_{0}=\sum_{k=1}^{\infty}\left[\left(\alpha+\lambda_{k}\right) \mu^{2}+\alpha \lambda_{k}\right]<\phi_{k}, \cdot>\phi_{k} .
$$

Lemma 4 [22,24] Let $\alpha \in R$. Then the pencil $\vec{B}$ is polynomially $A$-bounded and $\infty$ is nonessential singular point of the $A$-resolvent of pencil $\vec{B}$.

Remark 1. In the case (i) The $A$-spectrum of pencil $\vec{B} \quad \sigma^{A}(\vec{B})=\left\{\mu_{k}^{1,2}: k \in N\right\}$, where $\mu_{k}^{1,2}$ are the roots of equation

$$
\left(\lambda_{k}-\alpha\right) \mu^{2}-\alpha \lambda_{k}=0 .
$$

In the case (ii) $\sigma^{A}(\vec{B})=\left\{\mu_{l, k}^{1,2}: k \in N\right\}$, where $\mu_{l, k}^{1,2}$ are the roots of equation (14) for $\alpha \neq \lambda_{l}$.

Now check $(A)$. In the case (i) there exists an operator $A^{-1} \in L(F ; U)$, therefore $(A)$ is fulfilled. In the case (ii)

$$
\frac{1}{2 \pi i} \int_{\gamma^{k=1}}^{\infty} \frac{<\phi_{k}, \cdot>\phi_{k} d \mu}{\left(\lambda_{k}-\alpha\right) \mu^{2}-\alpha \lambda_{k}}=-\frac{1}{2 \pi i} \int_{\gamma^{k=1}}^{\infty} \frac{<\phi_{k}, \cdot>\phi_{k} d \mu}{\alpha \lambda_{k}}=0 .
$$

Construct the projectors. In the case (i) $P=I$ and $Q=I$, in the case (ii)

$$
P=I-\sum_{\alpha=\lambda_{k}}<\phi_{k}, \cdot>\phi_{k}
$$

and the projector $Q$ has the same form but is defined on the space $F$. Therefore, due to theorem 5 , the following theorem is true.

Theorem 6 [24] (i) Let $\alpha \notin \sigma(\Delta)$. Then the phase space of the equation is the entire space $U$, that is for all $v_{0}, v_{1} \in U$ there exists a unique solution of (12), (13), given by

$$
\begin{gathered}
v(z)=\sum_{\alpha<\lambda_{k}}<v_{0}, \phi_{k}>\phi_{k} \operatorname{ch} \sqrt{\frac{\alpha \lambda_{k}}{\lambda_{k}-\alpha}} z+\sum_{\alpha>\lambda_{k}}<v_{0}, \phi_{k}>\phi_{k} \cos \sqrt{\frac{\alpha \lambda_{k}}{\alpha-\lambda_{k}}} z+ \\
+\sum_{\alpha<\lambda_{k}}<v_{1}, \phi_{k}>\phi_{k} \sqrt{\frac{\lambda_{k}-\alpha}{\alpha \lambda_{k}}} \operatorname{sh} \sqrt{\frac{\alpha \lambda_{k}}{\lambda_{k}-\alpha}} z+\sum_{\alpha>\lambda_{k}}<v_{1}, \phi_{k}>\phi_{k} \sqrt{\frac{\alpha-\lambda_{k}}{\alpha \lambda_{k}}} \sin \sqrt{\frac{\alpha \lambda_{k}}{\alpha-\lambda_{k}}} z .
\end{gathered}
$$

(ii) Let $\alpha \in \sigma(\Delta)$. Then the phase space of the equation is the subspace $U^{1}$, that is for all

$$
v_{0}, v_{1} \in U^{1}=\left\{v \in U:\left\langle v, \phi_{k}>=0, \lambda=\lambda_{k}\right\}\right.
$$

there exists a unique solution of (12), (13), given by (15). 


\section{Математика}

Remark 2. The results if theorem 6can be easily transcribed in the terms of the initial equation2 (11), if we take into account the connection between the functions $u$ and $v$.

\section{The Boussinesq-Love equation on a geometrical graph}

Let $G=G(V ; E)$ be a finite connected oriented graph, where $V=\left\{V_{i}\right\}_{i=1}^{m}$ is the set of vertices, and $E=\left\{E_{j}\right\}_{j=1}^{n}$ is the set of edges. We suppose that each edge has the length $l_{j}>0$ and the cross section area $d_{j}>0$. On the graph $G$ consider the Boussinesq-Love equations [26]

$$
\lambda u_{j t t}-u_{j x x t t}=\alpha\left(u_{j x x t}-\lambda^{\prime} u_{j t}\right)+\beta\left(u_{j x x}-\lambda^{\prime \prime} u_{j}\right), x \in\left(0, l_{j}\right), t \in R, j=\overline{1, n} .
$$

At each vertex $V_{i}, i=\overline{1, m}$ set the boundary conditions

$$
\begin{gathered}
\sum_{j: E_{j} \in E^{\alpha}\left(V_{i}\right)} d_{j} u_{j x}(0, t)-\sum_{k: E_{k} \in E^{\omega}\left(V_{i}\right)} d_{k} u_{k x}\left(l_{k}, t\right)=0, \\
u_{s}(0, t)=u_{j}(0, t)=u_{k}\left(l_{k}, t\right)=u_{m}\left(l_{m}, t\right),
\end{gathered}
$$

for all $E_{s}, E_{j} \in E^{\alpha}\left(V_{i}\right), E_{k}, E_{m} \in E^{\omega}\left(V_{i}\right)$. Here by $E^{\alpha(\omega)}\left(V_{i}\right)$ we denote the set of edges starting (ending) in the vertex $V_{i}$. If we add the initial conditions

$$
u_{j}(x, 0)=u_{0 j}(x), u_{j t}(x, 0)=u_{1 j}(x) \text {, for all } x \in\left(0, l_{j}\right), j=\overline{1, n},
$$

then we get a problem describing the vibration processes in a construction made of thin elastic rods. The functions $u_{j}(x, t)$ determine the longitudinal displacement in the point $x$ at the moment $t$ on the $j$-th element of the construction. The parameters $\lambda, \lambda^{\prime}, \lambda^{\prime \prime}, \alpha$ and $\beta$ characterize the material if rods.

Reduce problem (17)-(19) for equations (16) to the Cauchy problem

$$
u(0)=u_{0}, u^{\prime}(0)=u_{1}
$$

for the linear Sobolev type equation of the second order

$$
A u^{\prime \prime}=B_{1} u^{\prime}+B_{0} u \text {. }
$$

By $L_{2}(G)$ denote a set

$$
L_{2}(G)=\left\{g=\left(g_{1}, g_{2}, \ldots, g_{j}, \ldots\right): g_{j} \in L_{2}\left(0, l_{j}\right)\right\} .
$$

The set $L_{2}(G)$ is a Hilbert space with an inner product

$$
<g, h>=\sum_{E_{j} \in E} d_{j} \int_{0}^{l_{j}} g_{j}(x) h_{j}(x) d x .
$$

By $U$ denote a set $U=\left\{u=\left(u_{1}, u_{2}, \ldots, u_{j}, \ldots\right): u_{j} \in W_{2}^{1}\left(0, l_{j}\right)\right.$ and (18) holds $\}$. The set $U$ is a Banach space with a norm

$$
\|u\|_{U}^{2}=\sum_{E_{j} \in E} d_{j} \int_{0}^{l_{j}}\left(u_{j x}^{2}(x)+u_{j}^{2}(x)\right) d x .
$$

Due to the Sobolev embedding theorems the space $W_{2}^{1}\left(0, l_{j}\right)$ consists of absolutely continuous functions, therefore $U$ is correctly defined, densely and compactly embedded in $L_{2}(G)$. Identify $L_{2}(G)$ with its dual space and by $F$ define a dual space to $U$ with respect to the duality $\langle\cdot, \cdot\rangle$. Obviously, $F$ is a Banach space and the embedding of $U$ into $F$ is compact.

By formula

$$
<D u, v>=\sum_{E_{j} \in E} d_{j} \int_{0}^{l_{j}}\left(u_{j x}(x) v_{j x}(x)+a u_{j}(x) v_{j}(x)\right) d x,
$$

where $a>0, u, v \in U$, set an operator defined on the space $U$. Fix $\alpha, \beta>0, \lambda, \lambda^{\prime}, \lambda^{\prime \prime} \in R$ and construct operators

$$
A=(\lambda-a) I+D, B_{1}=\alpha\left(\left(a-\lambda^{\prime}\right) I+D\right), B_{0}=\beta\left(\left(a-\lambda^{\prime \prime}\right) I+D\right) \text {. }
$$


Theorem 7 [23] Operators $A, B_{1}, B_{0} \in L(U ; F)$, moreover the spectrum $\sigma(A)$ of an operator $A$ is discrete, real tends only to $+\infty$.

So, the reduction of (16)-(19) to (20)-(21) is completed. By theorem 7, the operator $A$ is a Fredholm operator and ker $A=\{0\}$, if $0 \notin \sigma(A)$.

Lemma 5 [23] Let $\alpha, \lambda, \lambda^{\prime}, \lambda^{\prime \prime} \in R \backslash\{0\}$, then the operator pencil $\vec{B}$ is polynomially $A$-bounded, and $\infty$ is nonessential singular point of the A-resolvent of the pencil $\vec{B}$.

Remark 3 [23] It is easily seen that in the case $0 \in \sigma(A)$ and $\lambda=\lambda^{\prime}=\lambda^{\prime \prime}$ the operator pencil $\vec{B}$ is not polynomially $A$-bounded.

Remark 4. [23] $n$ the case $0 \notin \sigma(A)$ or $(0 \in \sigma(A)) \wedge\left(\lambda=\lambda^{\prime} \neq \lambda^{\prime \prime}\right)$ condition

$$
\int_{\gamma}\left(\mu^{2} A-\mu B_{1}-B_{0}\right)^{-1} d \mu=0
$$

where $\gamma=\{|\mu|=r>a\}, a$ is a constant from the definition of the polynomial $A$-boundedness, holds. In the case $(0 \in \sigma(A)) \wedge\left(\lambda \neq \lambda^{\prime}\right)$

$$
\int_{\gamma}\left(\mu^{2} A-\mu B_{1}-B_{0}\right)^{-1} d \mu \neq 0,
$$

therefore we exclude it from our future considerations when searching the phase space of the equation.

Let $\left\{\lambda_{k}\right\}$ be a set of eigenvalues of the operator $D$, numbered in nondecreasing order taking into account their multiplicities, and $\left\{\phi_{k}\right\}$ be a set of corresponding orthonormal in sense of $L_{2}(G)$ eigenfunctions. Construct the projectors

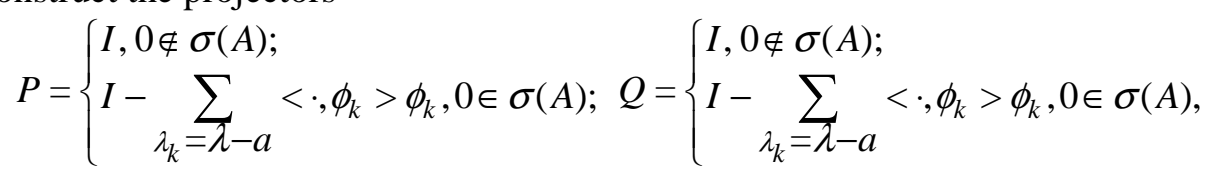

defined on spaces $U$ and $F$ respectively, and the propagators of equation (21)

$$
\begin{gathered}
V_{0}^{t}=\frac{1}{2 \pi i} \int_{\gamma}\left(\mu^{2} A-\mu B_{1}-B_{0}\right)^{-1}\left(\mu A-B_{1}\right) e^{\mu t} d \mu= \\
=\sum^{\prime}\left[\frac{\mu_{k}^{1}\left(\lambda-\left(a+\lambda_{k}\right)\right)+\alpha\left(\lambda^{\prime}-\left(a+\lambda_{k}\right)\right)}{\left(\lambda-\left(a+\lambda_{k}\right)\right)\left(\mu_{k}^{1}-\mu_{k}^{2}\right)} e^{\mu_{k}^{1} t}+\frac{\mu_{k}^{2}\left(\lambda-\left(a+\lambda_{k}\right)\right)+\alpha\left(\lambda^{\prime}-\left(a+\lambda_{k}\right)\right)}{\left(\lambda-\left(a+\lambda_{k}\right)\right)\left(\mu_{k}^{2}-\mu_{k}^{1}\right)} e^{\mu_{k}^{2} t}\right]<\cdot \phi_{k}>\phi_{k} ; \\
V_{1}^{t}(t)=\frac{1}{2 \pi i} \int_{\gamma}\left(\mu^{2} A-\mu B_{1}-B_{0}\right)^{-1} A e^{\mu t} d \mu=\sum \frac{e^{\mu_{k}^{1} t}-e^{\mu_{k}^{2} t}}{\left(\mu_{k}^{1}-\mu_{k}^{2}\right)}<\cdot \phi_{k}>\phi_{k},
\end{gathered}
$$

where $\sigma^{A}(\vec{B})=\left\{\mu_{k}^{1,2}: k \in N\right\}$, and $\mu_{k}^{1,2}$ are the roots of equation

$$
\left(\lambda-\left(a+\lambda_{k}\right)\right) \mu^{2}+\alpha\left(\lambda^{\prime}-\left(a+\lambda_{k}\right)\right) \mu+\beta\left(\lambda^{\prime \prime}-\left(a+\lambda_{k}\right)\right)=0 .
$$

Here the prime at the sum means the absence of summands with indices $k$ such that $\lambda=a+\lambda_{k}$. Hence the following theorem is true.

Theorem 8 [23, 24] Let $\alpha, \lambda, \lambda^{\prime}, \lambda^{\prime \prime} \in R \backslash\{0\}$ and

(i) $0 \notin \sigma(A)$.Then the phase space of (16) coincides with the space $U$, i.e. for all $u_{0}, u_{1} \in U$ there exists a unique solution $u \in C^{2}(R ; U)$ of (16)-(19), given by $u(t)=V_{0}^{t} u_{0}+V_{1}^{t} u_{1}$.

(ii) $0 \in \sigma(A)$ and $\lambda=\lambda^{\prime}$, but $\lambda \neq \lambda^{\prime \prime}$. Then the phase space of equation (16) coincides with the subspace $U^{1}=\left\{u \in U:\left\langle u, \phi_{k}\right\rangle=0\right.$ for $\left.\lambda_{k}=\lambda-a\right\}$, i.e. for all $u_{0}, u_{1} \in U^{1}$ there exists a unique solution $u \in C^{2}\left(R ; U^{1}\right)$ of (16)-(19), given by $u(t)=V_{0}^{t} u_{0}+V_{1}^{t} u_{1}$.

Remark 5. In the case $0 \in \sigma(A)$ and $\lambda \neq \lambda^{\prime}$ the phase space, in sense of definition 9, does not exist, since the condition of coordination of initial functions

$$
\mu_{k}<u_{0}, \phi_{k}>=<u_{1}, \phi_{k}>\text { for } \lambda_{k}=\lambda-a \text {. }
$$

is necessary for the existence of solution of the problem $[18,19]$. 


\section{Математика}

\section{Equation of ion-acoustic waves in plasma in external magnetic field}

Equation

$$
\frac{\partial^{2}}{\partial t^{2}}\left(\frac{\partial^{2}}{\partial t^{2}}+\omega_{B_{i}}^{2}\right)\left(\Delta_{3} \Phi-\frac{1}{r_{D}^{2}} \Phi\right)+\omega_{p_{i}}^{2} \frac{\partial^{2}}{\partial t^{2}} \Delta_{3} \Phi+\omega_{B_{i}}^{2} \omega_{p_{i}}^{2} \frac{\partial^{2} \Phi}{\partial x_{3}^{2}}=0
$$

firstly obtained by Yu.D. Pletner [27], describes the ion-acoustic waves in plasma in external magnetic field. The function $\Phi$ presents a generalized potential of the electric field, constants $\omega_{B_{i}}^{2}, \omega_{p_{i}}^{2}$, and $r_{D}^{2}$ characterize the ionic gyrofrequency, Langmuir frequency and the Debye radius, respectively. We transform equation (22) and consider the more general problem.

Let $\Omega=(0, a) \times(0, b) \times(0, c) \subset R^{3}$. In a cylinder $\Omega \times R$ consider the Cauhy-Dirichlet problem

$$
\begin{gathered}
v(x, 0)=v_{0}(x), \quad v_{t}(x, 0)=v_{1}(x), \\
v_{t t}(x, 0)=v_{2}(x), \quad v_{t t t}(x, 0)=v_{3}(x), \quad x \in \Omega \\
v(x, t)=0, \quad(x, t) \in \partial \Omega \times R
\end{gathered}
$$

for the equation

$$
(\Delta-\lambda) v_{t t t t}+\left(\Delta-\lambda^{\prime}\right) v_{t t}+\alpha \frac{\partial^{2} v}{\partial x_{3}^{2}}=0
$$

describing the ion-acoustic waves in plasma in external magnetic field. The initial-boundary value problem for (24) can be described in terms of problem (2) for equation (1), and negative values of the parameter $\lambda$ do not contradict the physical meaning of the problem. Reducing (23), (24) to (1), (2), set

$$
U=\left\{v \in W_{2}^{l+2}(\Omega): v(x)=0, x \in \partial \Omega\right\}, \quad F=W_{2}^{l}(\Omega),
$$

where $W_{2}^{l}(\Omega)$ are the Sobolev spaces. Operators $A, B_{3}, B_{2}, B_{1}$ and $B_{0}$ define by formulas $A=\Delta-\lambda$, $B_{2}=\left(\lambda^{\prime}-\Delta\right), B_{0}=\alpha \frac{\partial^{2} u}{\partial x_{3}^{2}}, B_{3}=B_{1}=O$. For all $l \in\{0\} \cup N$ operators $A, B_{1}, B_{0} \in L(U ; F)$.

For proof of the relative boundedness of the pencil $\vec{B}$ consider the eigenfunctions of the Laplace operator $\Delta$, defined in a domain $\Omega$, satisfying the boundary conditions from (23). Denote these eigenfnctions by $\phi_{k m n}=\left\{\sin \frac{\pi k x_{1}}{a} \sin \frac{\pi m x_{2}}{b} \sin \frac{\pi n x_{3}}{c}\right\}$, where $k, m, n \in N$, thus the eigenvalues $\lambda_{k m n}=-\left(k^{2}+m^{2}+n^{2}\right)$. Obviously, the spectrum $\sigma(\Delta)$ is negative, discrete, with finite multiplicities and tends only to $-\infty$. Since $\left\{\phi_{k}\right\} \subset C^{\infty}(\Omega)$, then

$$
\mu^{4} A-\mu^{3} B_{3}-\mu^{2} B_{2}-\mu B_{1}-B_{0}=\sum_{k, m, n=1}^{\infty}\left[\left(\lambda_{k m n}-\lambda\right) \mu^{4}+\left(\lambda_{k m n}-\lambda^{\prime}\right) \mu^{2}-\alpha\left(\frac{\pi n}{c}\right)^{2}\right]<\phi_{k m n}, \cdot>\phi_{k m n},
$$

where $\langle\cdot, \cdot\rangle$ is an inner product in $L^{2}(\Omega)$.

Lemma 6 [21]. (i) Let $\lambda \notin \sigma(\Delta)$. Then the pencil $\vec{B}$ is polynomially $A$-bounded and $\infty$ is a removable singular point of the $A$-resolvent of pencil $\vec{B}$.

(ii) $(\lambda \in \sigma(\Delta)) \wedge\left(\lambda \neq \lambda^{\prime}\right)$. Then the pencil $\vec{B}$ is polynomially $A$-bounded and $\infty$ is a pole of order 1 of the $A$-resolvent of pencil $\vec{B}$.

(iii) $(\lambda \in \sigma(\Delta)) \wedge\left(\lambda=\lambda^{\prime}\right)$. Then the pencil $\vec{B}$ is polynomially $A$-bounded and $\infty$ is a pole of order 3 of the $A$-resolvent of pencil $\vec{B}$.

Remark 6 [21] In case (i) of lemma 6 the $A$-spectrum of pencil $\vec{B}$ $\sigma^{A}(\vec{B})=\left\{\mu_{r m n}^{j}: r, m, n \in N, j=1, \ldots, 4\right\}$, where $\mu_{r m n}^{j}$ are the roots of equation

$$
\left(\lambda_{r m n}-\lambda\right) \mu^{4}+\left(\lambda_{r m n}-\lambda^{\prime}\right) \mu^{2}-\alpha\left(\frac{\pi n}{c}\right)^{2}=0
$$


and condition (A) holds. In case (ii) of lemma 6 the $A$-spectrum of pencil $\vec{B} \quad \sigma^{A}(\vec{B})=\left\{\mu_{l, k}^{j}: k \in N\right\}$, where $\mu_{l, k}^{j}$ are the roots of equation (25) with $\lambda=\lambda_{l}$, and condition $(A)$ does not hold. Therefore this case is excluded from the further considerations. In case (iii) of lemma 6 the $A$-spectrum of pencil $\vec{B}$ $\sigma^{A}(\vec{B})=\left\{\mu_{l, k}^{j}: k \in N, k \neq l\right\}$, and condition $(A)$ holds.

Construct the projectors. In case (i) of lemma $6 P=I$ and $Q=I$, in case (ii) of lemma 6

$$
P=I-\sum_{\lambda=\lambda_{k m n}}<\phi_{k m n}, \cdot>\phi_{k m n},
$$

and the projector $Q$ has the same form but is defined on the space $F$. In case (ii) construct the set

$$
U^{1}=\operatorname{im} P=\left\{v \in U: \sum_{\lambda=\lambda_{k m n}}<\phi_{k m n}, v>\phi_{k m n}=0\right\} .
$$

So, due to theorem 5 the following theorem is true.

Theorem 9 [21] (i) Let $\lambda \notin \sigma(\Delta)$. Then the phase space of (24) coincides with the space $U$, i.e. for all $v_{0}, v_{1}, v_{2}, v_{3} \in U$ there exists a unique solution $u \in C^{2}(R ; U)$ of (23), (24).

(ii) Let $\lambda \in \sigma(\Delta)$ and $\lambda=\lambda^{\prime}$. Then the phase space of equation (24) coincides with the subspace $U^{1}$, i.e. for all $v_{0}, v_{1}, v_{2}, v_{3}$ such that

$$
\sum_{\lambda_{k m n}=\lambda}<\phi_{k m n}, v_{j}>=0, j=0, \ldots, 3,
$$

there exists a unique solution $u \in C^{2}\left(R ; U^{1}\right)$ of (23), (24).

Remark 7. In case $(\lambda \in \sigma(\Delta)) \wedge\left(\lambda \neq \lambda^{\prime}\right)$ the phase space in sense of definition 9 , does not exist, since the condition of coordination of initial functions [19]:

$$
\left(\lambda_{k m n}-\lambda\right)<v_{2}, \phi_{k m n}>=\alpha\left(\frac{\pi n}{c}\right)^{2}<v_{0}, \phi_{k m n}>\text { при } \lambda_{k m n}=\lambda \text {. }
$$

is necessary for the existence of solution of the problem.

\section{References}

1. Sviridyuk G.A., Zagrebina S.A. The Showalter-Sidorov problem as a phenomena of the Sobolevtype equations. The Bulletin of Irkutsk State University. Series "Mathematics", 2010, Vol. 3, no. 1, pp. 51-72. (in Russ.).

2. Poincare H. Sur l'equilibre d'une mass fluide animee d'un mouvement de rotation. Acta Mathematica, 1885, Vol. 7, Issue 1, pp. 259-380. DOI:10.1007/BF02402204

3. Sobolev S.L. Ob odnoy novoy zadache matematicheskoy fiziki (On a new problem of mathematical physics). Izv. Akad. Nauk SSSR Ser. Mat., 1954, vol. 18, issue 1, p. 3-50. (in Russ.).

4. Demidenko G.V., Uspenskii S.V. Partial differential equations and systems not solvable with respect to the highest order derivative. N.Y.; Basel; Hong Kong: Marcel Dekker, Inc., 2003, 239 p. DOI: $10.1201 / 9780203911433$

5. Favini A., Yagi A. Degenerate differential equations in Banach spaces. N.Y.; Basel; Hong Kong: Marcel Dekker, Inc., 1999, 313 p.

6. Kozhanov A.I. On properties of solutions of one class of pseudoparabolic. Doklady Akad. Nauk SSSR, 1992, vol. 326, issue 5, p. 781-786. (in Russ.).

7. Showalter, R.E. Hilbert space methods for partial differential equations. Pitman; London; San Francisco; Melbourne, 1977, 208 p.

8. Sviridyuk, G.A., Fedorov V.E. Linear Sobolev type equations and degenerate semigroups of operators. Utrecht; Boston; Koln; Tokyo: VSP, 2003. 216 p. DOI: 10.1515/9783110915501.

9. Al'shin, A.B., Korpusov M.O., Sveshnikov A.G. Blow-up in nonlinear Sobolev type equations. De Gruyter, 2011, 648 p.

10. Zamyshlyaeva A.A. Lineynye uravneniya sobolevskogo tipa vysokogo poryadka (Linear Sobolev type equations of high order). Chelyabinsk, Publ. Center of the South Ural State University, 2012, 107 p. (in Russ.). 


\section{Математика}

11. Sagadeeva M.A. Dikhotomii resheniy lineynykh uravneniy sobolevskogo tipa (Dichotomy of solutions of linear Sobolev type equations). Chelyabinsk, Publ. Center of the South Ural State University, 2012. 139 p. (in Russ.).

12. Zagrebina S.A., Sagadeeva V.A. Ustoychivye i neustoychivye mnogoobraziya resheniy polulineynykh uravneniy sobolevskogo tipa (Stable and nonstable manifolds of solutions of semilinear Sobolev type equations). Chelyabinsk, Publ. Center of the South Ural State University, 2016. 121 p. (in Russ.).

13. Manakova N.A. Zadachi optimal'nogo upravleniya dlya uravneniy sobolevskogo tipa (Optimal control problem for the Sobolev type equations). Chelyabinsk, Publ. Center of the South Ural State University, 2012, 88 p. (in Russ.).

14. Sidorov N., Loginov, Sinithyn A., Falaleev M. Lyapunov-Shmidt methods in nonlinear analysis and applications. Dordrecht; Boston; London: Kluwer Academic Publishers, 2002, 568 p.

15. Kozhanov A.I. Kraevye zadachi dlya uravneniy matematicheskoy fiziki nechetnogo poryadka (Boundary problems for equations of mathematical physics of odd order). Novosibirsk, NGU Publ., 1990, 130 p. (in Russ.).

16. Pyatkov, S.G. Operator Theory. Nonclassical problems. Utrecht; Boston; Köln; Tokyo: VSP, 2002. 346 p. DOI: 10.1515/9783110900163

17. Manakova N.A., Sviridyuk G.A. Nonclassical equations of mathematical physics. Phase spaces of semilinear Sobolev type equations. Bulletin of South Ural State University. Series of "Mathematics. Mechanics. Physics", 2016, vol. 8, no. 3, pp. 31-51. (in Russ.).

18. Sviridyuk G.A., Apetova T.V. Fazovye prostranstva lineynykh dinamicheskikh uravneniy tipa Soboleva (Phase spaces of linear dynamical Sobolev type equations). Doklady Akad. Nauk, 1993, vol. 330, no. 6, p. 686. (in Russ.).

19. Sviridyuk G.A., Vakarina O.V. Lineynye uravneniya tipa Soboleva vysokogo poryadka (Linear Sobolev type equations of high). Doklady Akad. Nauk, 1998, vol. 393, no. 3, pp. 308-310. (in Russ.).

20. Zamyshlyaeva A.A. Phase spaces of one class of linear Sobolev type equations of the second order. Vychislitelnye tehnologii, 2003, vol. 8, no. 4, pp. 45-54. (in Russ.).

21. Zamyshlyaeva A.A. Stokhasticheskaya matematicheskaya model' ionno-zvukovykh voln v plazme (Stochastic mathematical model of ion-acoustic waves in plasma). Estestvennye i tekhnicheskie nauki (Razdel matematicheskoe modelirovanie, chislennye metody i kompleksy programm) (Natural and technical sciences (Mathematical modeling, numerical methods and program complexes)), 2013, vol. 4, pp. 284-292. (in Russ.).

22. Zamyshlyaeva A.A. De Gennes equation of acoustic waves in smectics. Obozrenie prikladnoy I promyshlennoy matematiki, 2009, Vol. 16, issue 4, pp. 655-656. (in Russ.).

23. Zamyshlyaeva A.A., Yuzeeva A.V. The initial-final value problem for the Boussinesque-Love equation on graph. Izvestia Irkutskogo gosudarsvennogo universiteta. Seria "Matematika", 2010, vol. 3, no. 2, pp. 18-29. (in Russ.).

24. Zamyshlyaeva A.A. Sobolev type mathematical models of high order. Bulletin of the South Ural State University. Series: Mathematical modelling, programming and computer software, 2014, vol. 7, no. 2, pp. 5-28. (in Russ.). DOI: 10.14529/mmp140201

25. Gabov S.A. Novye zadachi matematicheskoy teorii voln (New problems of mathematical wave theory). Moscow, Fizmatlit Publ., 1998, 448 p. (in Russ.).

26. Lyav A. Matematicheskaya teoriya uprugosti (Mathematical theory of elasticity). Moscow, Leningrad, ONTI Publ., 1935. 674 p. (in Russ.). [Love A.E.H., A Treatise on the Mathematical Theory of Elasticity, Cambridge University Press, 1927.]

27. Sveshnikov A.G., Alshin A.B., Korpusov M.O., Pletner Yu.D. Linear and nonlinear Sobolev type equations. Moscow, Fizmatlit Publ., 2004, 736 p. (in Russ.).

Received September 27, 2016 


\title{
НЕКЛАССИЧЕСКИЕ УРАВНЕНИЯ МАТЕМАТИЧЕСКОЙ ФИЗИКИ. ЛИНЕЙНЫЕ УРАВНЕНИЯ СОБОЛЕВСКОГО ТИПА ВЫСОКОГО ПОРЯДКА
}

\author{
А.А. Замышляева, Г.А. Свиридюк \\ Южно-Уральский государственный университет, г. Челябинск, Российская Федерация \\ E-mail: zamyshliaevaaa@susu.ru
}

Статья содержит обзор результатов авторов в области неклассических уравнений математической физики. Представлена теория линейных уравнений соболевского типа высокого порядка. Идея базируется на обобщении теории вырожденных (полу)групп операторов на случай указанных уравнений: расщеплении пространств, действий всех операторов, построении пропагаторов и фазового пространства однородного уравнения, а также множества допустимых начальных значений для неоднородного уравнения. Использован уже хорошо зарекомендовавший себя при решении уравнений соболевского типа метод фазового пространства, заключающийся в редукции сингулярного уравнения к регулярному, определенному на некотором подпространстве исходного пространства. Однако, в отличие от уравнений первого порядка, в данном случае возникает дополнительное условие, гарантирующее существование фазового пространства, и имеются примеры, когда для разрешимости задачи Коши начальные условия необходимо согласовывать между собой при невыполнении этого условия. В работе проводится редукция неклассических уравнений математической физики к начальным (начально-конечным) задачам для абстрактного уравнения соболевского типа высокого порядка.

Ключевые слова: неклассические уравнения математической физики; уравнения соболевского типа высокого порядка; фазовое пространство; пропагаторы.

\section{Литература}

1. Свиридюк, Г.А. Задача Шоуолтера-Сидорова как феномен уравнений соболевского типа / Г.А. Свиридюк, С.А. Загребина // Известия Иркутского государственного университета. Серия «Математика». - 2010. - Т. 3, № 1. - С. 104-125.

2. Poincare, H. Sur l'equilibre d'une mass fluide animee d'un mouvement de rotation / H. Poincare // Acta Math. - 1885. - V. 7. - P. 259-380.

3. Соболев, С.Л. Об одной новой задаче математической физики / С.Л. Соболев // Изв. АН СССР, серия «Математика». - 1954. - Т. 18, вып. 1. - С. 3-50.

4. Demidenko, G.V. Partial differential equations and systems not solvable with respect to the highest order derivative / G.V. Demidenko, S.V. Uspenskii. - N.Y.; Basel; Hong Kong: Marcel Dekker, Inc., 2003. -239 p.

5. Favini A. Degenerate differential equations in Banach spaces / A. Favini, A. Yagi. - N.Y.; Basel; Hong Kong: Marcel Dekker, Inc., 1999. - 313 p.

6. Кожанов А.И. О свойствах решений для одного класса псевдопараболических уравнений // ДАН СССР. 1992. - Т. 326, № 5. - С. 781-786.

7. Showalter, R.E. Hilbert space methods for partial differential equations / R.E. Showalter. - Pitman; London; San Francisco; Melbourne, 1977. - 208 p.

8. Sviridyuk, G.A. Linear Sobolev type equations and degenerate semigroups of operators / G.A. Sviridyuk, V.E. Fedorov. - Utrecht; Boston; Köln; Tokyo: VSP, 2003. - 216 p.

9. Al'shin, A.B. Blow-up in nonlinear Sobolev type equations / A.B. Al'shin, M.O. Korpusov, A.G. Sveshnikov. - De Gruyter, 2011. - 648 c.

10. Замышляева, А.А. Линейные уравнения соболевского типа высокого порядка / А.А. Замышляева. - Челябинск: Изд. центр ЮУрГУ, 2012. - 107 с. 


\section{Математика}

11. Сагадеева, М.А. Дихотомии решений линейных уравнений соболевского типа / М.А. Сагадеева. - Челябинск: Изд. центр ЮУрГУ, 2012. - 139 с.

12. Загребина, С.А. Устойчивые и неустойчивые многообразия решений полулинейных уравнений соболевского типа / С.А. Загребина, М.А. Сагадеева. - Челябинск: Изд. центр ЮУрГУ, 2016. $-121 \mathrm{c}$.

13. Манакова, Н.А. Задачи оптимального управления для уравнений соболевского типа / Н.А. Манакова. - Челябинск: Изд. центр ЮУрГУ, 2012. - 88 с.

14. Lyapunov-Shmidt methods in nonlinear analysis and applications / N. Sidorov, B. Loginov, A. Sinithyn, M. Falaleev. - Dordrecht; Boston; London: Kluwer Academic Publishers, 2002. - 568 p.

15. Кожанов, А.И. Краевые задачи для уравнений математической физики нечетного порядка / А.И. Кожанов. - Новосибирск: НГУ, 1990. - 130 с.

16. Pyatkov, S.G. Operator Theory. Nonclassical Problems / S.G. Pyatkov. - Utrecht; Boston; Köln; Tokyo: VSP, 2002. - 346 p.

17. Манакова, Н.А. Неклассические уравнения математической физики. Фазовые пространства полулинейных уравнений соболевского типа / Н.А. Манакова, Г.А. Свиридюк // Вестник ЮУрГУ. Серия «Математика. Механика. Физика». - 2016. - Т. 8, № 3. - С. 31-51.

18. Свиридюк, Г.А. Фазовые пространства линейных динамических уравнений типа Соболева / Г.А. Свиридюк, Т.В. Апетова // Доклады Академии наук. - 1993. - Т. 330, № 6. - С. 696.

19. Свиридюк, Г.А. Линейные уравнения типа Соболева высокого порядка / Г.А. Свиридюк, О.В. Вакарина // ДАН. - 1998. - Т. 393, № 3. - С. 308-310.

20. Замышляева, А.А. Фазовые пространства одного класса линейных уравнений соболевского типа второго порядка / А.А. Замышляева // Вычислит. технол. - 2003. - Т. 8, № 4. - С. 45-54.

21. Замышляева, А.А. Стохастическая математическая модель ионно-звуковых волн в плазме / А.А. Замышляева // Естественные и технические науки (Раздел математическое моделирование, численные методы и комплексы программ). - 2013. - № 4. - С. 284-292.

22. Замышляева, А.А. Уравнение de Gennes звуковых волн в смектиках / А.А. Замышляева // Обозрение прикладной и промышленной математики. - 2009. - Т. 16, вып. 4. - С. 655-656.

23. Замышляева, А.А. Начально-конечная задача для уравнения Буссинеска-Лява на графе / А.А. Замышляева, А.В. Юзеева // Известия Иркутского государственного университета. Серия «Математика». - 2010. - Т. 3, № 2. - С. 18-29.

24. Замышляева, А.А. Математические модели соболевского типа высокого порядка / А.А. Замышляева // Вестник ЮУрГУ. Серия «Математическое моделирование и программирование». - 2014. - T. 7, № 2. - C. 5-28.

25. Габов, С.А. Новые задачи математической теории волн / С.А. Габов. - М.: Физматлит, 1998. $-448 \mathrm{c}$.

26. Ляв, А. Математическая теория упругости / А. Ляв. - Москва; Ленинград: ОНТИ, 1935. $674 \mathrm{c}$.

27. Линейные и нелинейные уравнения соболевского типа / А.Г. Свешников, А.Б. Альшин, М.О. Корпусов, Ю.Д. Плетнер. - М.: Физматлит, 2004. - 736 с.

Поступила в редакцию 27 сентября 20162. 